\title{
Modeling Heat Loss from the Udder of a Dairy Cow
}

Kifle G. Gebremedhin and Binxin $\mathrm{Wu}^{1}$

\section{Abstract}

A mechanistic model that predicts sensible and latent heat fluxes from the udder of a dairy cow was developed. The prediction of the model was spot validated against measured data from the literature, and the result agreed within $7 \%$ of the measured value for the same ambient temperature. A dairy cow can lose a significant amount of heat $\left(388 \mathrm{~W} / \mathrm{m}^{2}\right)$ from the udder. This suggests that the udder could be considered as a heat sink. The temperature profile through the udder tissue (core to skin) approached the core temperature for an air temperature $\geq 37^{\circ} \mathrm{C}$ whereas the profile decreased linearly from the core to skin surface for an air temperature less than $37^{\circ} \mathrm{C}$. Sensible heat loss was dominant when ambient air temperature was less than $37.5^{\circ} \mathrm{C}$

14 but latent heat loss was greater than sensible heat loss when air temperature was $\geq 37.5^{\circ} \mathrm{C}$. The 15 udder could lose a total (sensible + latent) heat flux of $338 \mathrm{~W} / \mathrm{m}^{2}$ at an ambient temperature of $1635^{\circ} \mathrm{C}$ and blood-flow rate of $3.2 \times 10^{-3} \mathrm{~m}^{3} /\left(\mathrm{s} \cdot \mathrm{m}^{3}\right.$ tissue $)$. The results of this study suggests that, in

17 time of heat stress, a dairy cow could be cooled by cooling the udder only (e.g., using an

18 evaporative cooling jacket).

19 Keywords: Udder, Dairy cow, Model, Heat flux, Heat stress

\section{Introduction}

22 Heat stress is a major factor in the economics of dairy farming, especially with high-producing

23 Holstein dairy cows. Economic losses due to reduced milk yield caused by heat stress have been

24 estimated to be approximately 1.5 billion dollars per year nationally (St-Pierre et al., 2003). In

25 addition, there are losses due to negative effects on reproductive performance and the associated

26 costs of breeding a cow and losses in genetic gains (al-Katanani et al., 1999; Jordan, 2003).

27 Needless to say, reducing the effect of summer heat stress on dairy cows is very important to the

2840 billion-dollar U.S. dairy industry.

The udder can be characterized as a heat sink because looking at the thermal image (infrared

31 thermography) of a cow, the eye and the udder are at higher temperature than at any exterior part

32 of the cow (thecattlesite.com, 2010). Gebremedhin et al. (2013) also reported a uniform thermal

${ }^{1}$ Professor and Senior Research Associate, Department of Biological and Environmental Engineering, Cornell University, Ithaca, NY 14853. 
33 image of the udder, which confirms the uniformity of blood flow within the skin surface of the

34 udder. Bitman et al. (1984) also reported that the internal-body and udder temperatures were

35 highly correlated (the correlation coefficient was 0.98-0.99 in each cow). They reported that the

36 mean core and udder temperature was found to be $38.84^{\circ} \mathrm{C}$. This is because a large volume of

37 blood circulates through the udder. Similarly, Smith et al. (1977) studied the role of heat loss

38 from the udder in sheep and reported that the udder remained at a relatively constant temperature

39 despite changes in air temperature. The same study found no correlation between time of day and

40 udder temperature. This might be due to thermal regulation of blood flow in the udder.

42 Several other studies (Peeters et al., 1979; Mustafa, 2001; Anderson, 1985; Hurley, 2010)

43 reported that as much as 400 to 500 liters of blood is needed to pass through the udder to produce

441 liter of milk. The rate of blood flow is, however, affected by breed (Al-Ani et al., 1985) and

45 stage of lactation (Al-Ani and Vesweber, 1984). Given that these studies were conducted 20

46 years ago and that milk production of Holstein cows has been increasing at a rate of $1.5-2.0 \%$

47 per year (Foreign Agricultural Service/USDA, 2015). It is, therefore, reasonable to assume that

48 the volume of blood flow through the udder for current high-producing dairy cows could be

49 higher.

51 The fact that the udder temperature is as high as the core-body temperature leads to the idea that

52 cooling the udder is essentially cooling the large volume of blood passing through it. Cooling the

53 udder only would be an effective and efficient way to cool a cow because less water would be

54 required to wet a smaller surface area compared to wetting the entire body surface in time of heat

55 stress. This was experimentally validated by Gebremedhin et al. (2013) who reported that there

56 was no significant difference in mean rectal temperature between wetting the udder only and

57 wetting the entire body of a cow. In addition to cooling the blood almost directly, there is much

58 less hair on the skin of the udder compared to the rest of the body of a cow, and hair coat is an

59 obstruction to evaporative cooling (Gebremedhin et al, 2010). The challenge to udder cooling

60 only is to come up with an udder cooling system that works in a production setting.

61 Gebremedhin et al. (2013) suggested the use of an evaporation cooling jacket that could be

62 mounted onto the udder. 
64 The objectives of this study were: (1) to develop a mechanistic model that predicts sensible and

65 latent heat losses from the udder of a dairy cow at varying ambient temperature, and (2) to

66 conduct sensitivity analyses of heat loss with respect to changes in volumetric blood flow rate

67 and blood circulation time to the udder. Based on our extensive search, there exists no

68 mechanistic model that predicts sensible and latent heat losses from the udder. The only study

69 we found was that by Janeczek et al. (1995) who reported specific measurements of heat flux and

70 temperature changes of the udder during and after milking. The heat flux measurement from this

71 study (Janeczek et al., 1995) was used to spot validate our predicted heat flux.

73 Model Development

74 Assumptions:

75 1. Cow udder is semi sphere

76 2. Radius of the semi sphere is $0.17 \mathrm{~m}$

77 3. An outer layer of 10-mm thickness of tissue was assumed for heat transfer between the udder 78 and ambient air (Figure 1).

79 4. A one-dimensional transient (a function of time) heat flow was assumed through the thickness 80 of the tissue (Figure 1).

81 5. Heat lost from the udder skin surface when the cow is standing is by evaporation and 82 convection

83 6. Core temperature of udder tissue is $38.6^{\circ} \mathrm{C}$

84 7. Metabolic heat production rate in the tissue is $1,946 \mathrm{~W} / \mathrm{m}^{3}$

85 8. Blood-flow time through the udder takes between 2-4min.

86 9. The physical and thermal properties are assumed to be constant

87 10. Temperature of blood entering the udder is equal to core temperature.

\section{$89 \quad$ Heat transfer model}

90 The energy equation for the tissue domain was based on Penne's Bio-heat Equation (Pennes,

91 1948). It is a nonlinear-conduction equation that is meant for biological tissues with added

92 advection (convection) heating by infused blood flow. The equation given below is broken

93 down into four terms: a transient term, a simple Fourier's Law conduction term, a nonlinear 
94 advection term for the infused blood flow at a given temperature, and a source generation term,

95 respectively, and is expressed as

96

$97 \quad \rho c \frac{\partial T}{\partial t}=\frac{\partial}{\partial x}\left(k \frac{\partial T}{\partial x}\right)+\rho_{b} c_{b} \dot{V}_{b}\left(T_{b}-T\right)+Q_{m}$

98 where, $\rho$ is tissue density $\left(\mathrm{kg} / \mathrm{m}^{3}\right), \mathrm{c}$ is tissue specific heat $(\mathrm{J} / \mathrm{kg} \cdot \mathrm{K}), \mathrm{T}$ is tissue temperature $(\mathrm{K}), \mathrm{t}$

99 is time (s), $\mathrm{k}$ is tissue thermal conductivity $(\mathrm{W} / \mathrm{m} \cdot \mathrm{K}), \rho_{\mathrm{b}}$ is blood density $\left(\mathrm{kg} / \mathrm{m}^{3}\right), \mathrm{c}_{\mathrm{b}}$ is blood

100 specific heat $(\mathrm{J} / \mathrm{kg} \cdot \mathrm{K}), \dot{V}_{b}$ is flow rate of blood into tissue $\left(\mathrm{m}^{3} \mathrm{blood} / \mathrm{s}\right.$ per $\mathrm{m}^{3}$ tissue $), \mathrm{T}_{\mathrm{b}}$ is blood

101 inlet temperature $(K)$, and $Q_{m}$ is metabolic heat production rate in the tissue $\left(\mathrm{W} / \mathrm{m}^{3}\right)$.

102 Equation (1) can be expressed in a simple form as

$103 \rho c \frac{\partial T}{\partial t}=\frac{\partial}{\partial x}\left(k \frac{\partial T}{\partial x}\right)+S$

104 where, the source term, $\mathrm{S}$, is expressed as

$105 S=\rho_{b} c_{p, b} \dot{V}_{b}\left(T_{b}-T\right)+Q_{m}$

106 The discretization equation that is derived by integrating Eq. (2) over the control volume shown

107 in Figure 2 and over the time interval from $t$ to $(t+\Delta t)$ can be expressed as (Patankar, 1980)

$108 \rho c \int_{w}^{e} \int_{t}^{t+\Delta t} \frac{\partial T}{\partial t} d t d x=\int_{t}^{t+\Delta t} \int_{w}^{e} \frac{\partial}{\partial x}\left(k \frac{\partial T}{\partial x}\right) d x d t+\int_{t}^{t+\Delta t} \int_{w}^{e} S d x d t$

109 where,

$110 \rho c \int_{w}^{e} \int_{t}^{t+\Delta t} \frac{\partial T}{\partial t} d t d x=\rho c \Delta x\left(T_{P}-T_{P}^{0}\right)$

$111 \int_{t}^{t+\Delta t} \int_{w}^{e} \frac{\partial}{\partial x}\left(k \frac{\partial T}{\partial x}\right) d x d t=\left[\frac{k_{e}\left(T_{E}-T_{P}\right)}{(\delta x)_{e}}-\frac{k_{w}\left(T_{P}-T_{W}\right)}{(\delta x)_{w}}\right] \Delta t$

$112 \int_{t}^{t+\Delta t} \int_{w}^{e} S d x d t=\bar{S} \Delta x \Delta t$ 
113 where, $\mathrm{T}_{\mathrm{P}}$ is temperature at Node $\mathrm{P}, \mathrm{T}_{\mathrm{W}}$ and $\mathrm{T}_{\mathrm{E}}$ are temperatures at Node $\mathrm{W}$ and $\mathrm{E}$, respectively,

114 (See Fig. 2), $\mathrm{T}_{\mathrm{P}}^{0}$ is the temperature at previous iteration, $\mathrm{k}$ is conductivity at the control surfaces

115 (at e and w), $\bar{S}$ is the average value of $\mathrm{S}$ over the control volume, which can be expressed as

$116 \bar{S}=S_{C}+S_{P} T_{P}$

117 where, $\mathrm{S}_{\mathrm{C}}$ represents the constant part of $\bar{S}$, and $\mathrm{S}_{\mathrm{P}}$ is the coefficient of $\mathrm{T}_{\mathrm{P}}$.

118 Rearranging Eqs. (5), (6), and (7), the fully implicit discretization equation can be expressed as

$119 a_{P} T_{P}=a_{E} T_{E}+a_{W} T_{W}+b$

120 where,

$121 \quad a_{E}=\frac{k_{e}}{(\delta x)_{e}}$

$122 \quad a_{W}=\frac{k_{w}}{(\delta x)_{w}}$

$123 b=S_{C} \Delta x+a_{P}^{0} T_{P}^{0}$

$124 \quad a_{P}^{0}=\frac{\rho c \Delta x}{\Delta t}$, and

$125 a_{P}=a_{E}+a_{W}+a_{P}^{0}-S_{P} \Delta x$

126

127 Boundary conditions

128 Two boundary conditions are required to solve Eq. (9) and they are:

129 (1) The temperature at $\mathrm{x}=0$, which is at the inside of the udder (Fig. 1) is equal to the core 130 temperature, expressed as

$\left.131 \quad T\right|_{x=0}=T_{c}$

132 (2) At $x=L$, which is at the skin surface (Fig. 1), the heat flux conducted is equal to the sum 133 of the heat flux convected and evaporated, expressed as 
$134-\left.k \frac{\partial T}{\partial x}\right|_{x=L}=h_{c}\left(T_{s}-T_{a}\right)+\left[31.5+e^{\left(T_{s}-27.9\right) / 2.19115}\right]$

135 where, $T_{c}$ is core temperature of the udder, $T_{s}$ is temperature of the udder skin surface, $T_{a}$ is

136 ambient temperature, $h_{c}$ is convective heat transfer coefficient of the udder when the cow is

137 standing, and L is udder tissue thickness (Fig. 1). The second term on the right side of Eq. (16) is

138 the evaporative heat loss from the udder skin (da Silva and Maia, 2011).

139

140 The convective heat transfer coefficient, $h_{c}$, can be obtained from Nusselt number $(\mathrm{Nu})$ as

141 (Gebremedhin and $\mathrm{Wu}, 2001$ )

$142 N u=\frac{h_{c} d}{k}=\left\{\begin{array}{cc}\left(0.43+0.50 \operatorname{Re}^{0.50}\right) \operatorname{Pr}^{0.38} & 1<\operatorname{Re}<10^{3} \\ 0.25 \operatorname{Re}^{0.6} \operatorname{Pr}^{0.38} & 10^{3}<\operatorname{Re}<2 \times 10^{5}\end{array}\right.$

143 where, Pr is the Prandtl number assumed to be 0.7 , and Re is Reynold number calculated by

$144 \quad \operatorname{Re}=\frac{\rho_{a} u d}{\mu}$

145 where, $\rho_{\mathrm{a}}$ is air density, $\mathrm{u}$ is air velocity across the udder, $\mathrm{d}$ is udder diameter, and $\mu$ is dynamic 146 viscosity of air.

147

\section{Numerical simulation}

149 The algebraic Eq. (9) can be solved by tri-diagonal matrix algorithm (Patankar, 1980). The grid 150 points are numbered $1,2,3, \ldots, \mathrm{N}$, in which points 1 and $\mathrm{N}$ denote the boundary points.

151 Equation (9) can be written as

$152 a_{i} T_{i}=b_{i} T_{i+1}+c_{i} T_{i-1}+d_{i}$

153 If $T_{i-1}$ is expressed as

$154 \quad T_{i-1}=P_{i-1} T_{i}+Q_{i-1}$

155 Then, Eq. (19) can be written as

$156 a_{i} T_{i}=b_{i} T_{i+1}+c_{i}\left(P_{i-1} T_{i}+Q_{i-1}\right)+d_{i}$

157 where, the coefficients $P_{i}$ and $Q_{i}$ are expressed as

$158 \quad P_{i}=\frac{b_{i}}{a_{i}-c_{i} P_{i-1}}$ 
$159 Q_{i}=\frac{d_{i}+c_{i} Q_{i-1}}{a_{i}-c_{i} P_{i-1}}$

160 The values of $\mathrm{P}_{1}$ and $\mathrm{Q}_{1}$ for $\mathrm{i}=1$ are given by

$161 \quad P_{1}=\frac{b_{1}}{a_{1}}$

$162 Q_{1}=\frac{d_{1}}{a_{1}}$

163 Since $b_{N}=0$, then $P_{N}=0$ for $i=N$, and the temperature, $T_{N}$ can be obtained by

$164 T_{N}=Q_{N}$

165 The solution procedure for tri-diagonal matrix algorithm can be summarized as follows:

166 1. Calculate $P_{1}$ and $Q_{1}$ from Eqs. (24) and (25)

167 2. Solve $\mathrm{P}_{\mathrm{i}}$ and $\mathrm{Q}_{\mathrm{i}}$ from Eqs. (22) and (23)

$168 \quad$ 3. $\operatorname{Set} T_{N}=Q_{N}$

169

4. Solve $\mathrm{T}_{\mathrm{N}-1} . \mathrm{T}_{\mathrm{N}-2}, \ldots, \mathrm{T}_{3}, \mathrm{~T}_{2}, \mathrm{~T}_{1}$ from Eq. (20).

170

171 Results and Discussion

172 In this study, eleven computational grids and one second time size were used to run the 173 calculations for the temperature profile. In order to solve Eq. (1), the Penne's Bio-heat Equation, 174 two fluids (blood and air) and one solid (tissue) were involved. The physical and thermal 175 properties used in this study are given in Table 1.

177 Given the two boundary conditions specified previously, the temperature profile through the

178 udder tissue was predicted by solving the algebraic equation (Eq. 9). Once the temperature

179 profile was defined, heat flux was calculated. The temperature profile through the udder tissue

180 approached the core temperature for an air temperature $\geq 37^{\circ} \mathrm{C}$ but decreased linearly from the 181 core to skin surface for an air temperature less than $37^{\circ} \mathrm{C}$ (Fig. 3). The temperature of the udder 182 skin surface was $33.2,36.0$ and $38.2^{\circ} \mathrm{C}$ for ambient air temperature of 30,34 , and $37^{\circ} \mathrm{C}$, 183 respectively, (Fig. 3). For these simulations, the core temperature was kept constant at $38.5^{\circ} \mathrm{C}$.

185 Sensible heat loss from the udder decreased linearly with increasing ambient air temperature but 186 evaporative heat loss increased exponentially (Fig. 4). This is consistent with the boundary 
187 conditions expressed by Eq. (16) where the convection term is a function of the temperature 188 gradient between the skin surface and ambient $\left(\mathrm{T}_{\mathrm{s}}-\mathrm{T}_{\mathrm{a}}\right)$ in a linear fashion whereas the evaporation 189 heat loss term is an exponential function of the udder skin temperature $\left(\mathrm{T}_{\mathrm{s}}\right)$. At an air temperature 190 less than $37.5^{\circ} \mathrm{C}$, sensible heat loss from the udder was greater than latent heat loss (Fig. 4). At 191 an air temperature greater than $37.5^{\circ} \mathrm{C}$, latent heat loss was larger than convective heat loss.

192 Figure 4 also shows that the total heat flux from the udder decreased with increasing (from 30 to $19337.5^{\circ} \mathrm{C}$ ) ambient air temperature. This was the range where sensible heat loss was dominant.

194 When air temperature was greater than $37.5^{\circ} \mathrm{C}$, where latent heat loss was greater than sensible 195 heat loss, the total heat loss started to increase.

197 The predicted total heat flux from the udder ranged from 292 to $360 \mathrm{~W} / \mathrm{m}^{2}$ for blood circulation 198 time of 2 and 4 min., respectively, while keeping the following parameters constant: ambient air 199 temperature $=35{ }^{\circ} \mathrm{C}$, average wind speed $=1.0 \mathrm{~m} / \mathrm{s}$, blood-flow rate $=3.2 \times 10^{-3} \mathrm{~m}^{3} /\left(\mathrm{s} \cdot \mathrm{m}^{3}\right.$ tissue $)$ 200 (Table 2). The blood-flow rate value used in this study was reported by Gorewit et al. (1989) 201 who used a transit time ultrasonic blood flow metering system to study the arterial blood flow in 202 the mammary glands of four lactating Holstein cows. Generally, sensible heat flux increases with 203 increasing blood-circulation time through the udder. Based on Eq. (1), which is a transient heat 204 transfer equation, the temperature at each computational node is directly proportional to time.

205 Keeping constant ambient air temperature of $35^{\circ} \mathrm{C}$ and an average air velocity of $1 \mathrm{~m} / \mathrm{s}$, but 206 increasing the udder-skin surface temperature through continuous blood flow results in a higher 207 temperature gradient between the udder-skin surface and the environment, and therefore,

208 increases the heat loss by convection. The increase in latent heat loss with blood-circulation time 209 was, however, very small compared to the sensible heat loss because evaporative heat transfer is 210 not a function of blood circulation time (Eq. 1).

212 Table 3 shows the sensitivity of heat flux with respect to blood-flow rate. Two arbitrary blood213 flow rates, one smaller and another greater than $3.2 \times 10^{-3} \mathrm{~m}^{3} /\left(\mathrm{s} \cdot \mathrm{m}^{3}\right.$ tissue $)$ were taken to see the 214 sensitivity of heat flux. The total heat flux decreased by $8.7 \%$ for the lower blood-flow rate and 215 increased by $6.8 \%$ for the higher blood-flow rate. 
217 Janeczek et al. (1995) reported a measured mean heat flux of $1234 \pm 247.5 \mathrm{~W} / \mathrm{m}^{2}$ at the back of

218 the udder for mean air temperature of $15.8^{\circ} \mathrm{C}$, a mean relative humidity of $70.8 \%$ and core

219 temperature of $38.6^{\circ} \mathrm{C}$. Using our model, the predicted heat flux was $1325 \mathrm{~W} / \mathrm{m}^{2}$ for the same air

220 temperature and core temperature, blood-flow rate of $3.2 \times 10^{-3} \mathrm{~m}^{3} /\left(\mathrm{s} \cdot \mathrm{m}^{3}\right.$ tissue) and blood-flow

221 time of 3min. The blood-flow rate and blood-flow time for the Janeczek et al. (1995) study was

222 not known. The spot validation show that the predicted result agreed within $7 \%$ of the measured

223 heat flux. We recognize, however, that the parts of the udder (front and side surfaces) that are

224 protected from wind by body parts (legs and belly) would be exposed to lower wind speed than

225 the back of the udder, and thus would have less convective heat loss.

226

\section{Conclusions}

228 The following specific conclusions could be drawn from this study:

229 1. A mechanistic model that predicts sensible and latent heat fluxes from the udder of a dairy cow was developed. A prediction of the model was spot validated against measured flux data from the literature and the result agreed within $7 \%$ of the measured data. It was predicted that a cow could lose $388 \mathrm{~W} / \mathrm{m}^{2}$ of total (sensible +latent) heat flux from the udder at $35^{\circ} \mathrm{C}$ ambient air temperature and $3.2 \times 10^{-3} \mathrm{~m}^{3} /\left(\mathrm{s} \cdot \mathrm{m}^{3}\right.$ tissue $)$ blood-flow rate. This suggests that the udder could be considered as a heat sink, and thus, in time of heat stress, a dairy cow could be cooled by cooling the udder only using an evaporation cooling jacket that could function in a production setting.

2. The temperature profile through the udder tissue approached the core temperature for an air temperature $\geq 37^{\circ} \mathrm{C}$ but decreased linearly from the core to the skin surface for an air temperature less than $37^{\circ} \mathrm{C}$. The temperature of the udder skin was $33.2,36.0$ and $38.2^{\circ} \mathrm{C}$ for air temperature of 30,34 , and $37^{\circ} \mathrm{C}$, respectively. For these simulations, the core temperature was kept constant at $38.5^{\circ} \mathrm{C}$.

3. Sensible heat loss was dominant when ambient air temperature was less than $37.5^{\circ} \mathrm{C}$ but latent heat loss was greater than sensible heat loss when air temperature was $\geq 37^{\circ} \mathrm{C}$. 
249 This project was funded by the United States Department of Agriculture (USDA/ HATCH funds 250 as part of the W-273 Regional Project through Cornell University.

\section{References}

Al-Ani, F.K. and J.G.E. Vestweber, 1984. Mammary blood flow measurement associated with development of bovine udder edema. Amer. J. Vet. Res. 45(2) 339-341.

Al-Ani, F.K., J.G. Vestweber, and H.W. Leipold. 1985. Blood flow parameters associated with udder edema in Jersey cattle affected with rectovaginal constriction. Vet. Rec. 116(6) 156-158.

al-Katanani, Y.M., D.W. Webb and P.J. Hansen. 1999. Factors affecting seasonal variation in

90-day non-return rate to first service in lactating Holstein cows in hot climate. Journal of Dairy Science. 82(12) 2611-2616.

Anderson, R.R. 1985. Mammary gland in Lactation by Anderson, R.R., R.J. Collier, C.W. Heald, R. Jenness, B.L. Larson and H.A. Tucker; ed. Larson, B.L. Pub. by the Iowa State University Press, p. 30-31.

Bitman J., A. Lefcourt, D. L. Wood, and B. Stroud. 1984. Circadian and ultradian temperature rhythms of lactating dairy cows. J. Dairy Science 67(5):1014-1023.

da Silva, R. G., and A.S.C. Maia. 2011. Evaporative cooling and cutaneous surface temperature of Holstein cows in tropical conditions. Revista Brasileira de Zootecnia. 40(5):1143-1147.

Foreign Agricultural Service/USDA, Office of Global Analysis. December 2015. Dairy: World markets and trade.

Gebremedhin, K.G., C.N. Lee, J. Davis and J. Larson. 2013. Alternative cooling of dairy cows by udder wetting. Transactions of ASABE, 56(1):305-310.

Gebremedhin, K.G., C.N. Lee, P.E. Hillman, and R.J. Collier. 2010. Physiological responses of dairy cows during extended solar exposure. Transactions of ASABE. 53(1) -239-247.

Gebremedhin, K.G., and B. Wu. 2001. A model of evaporative cooling of wet skin surface and fur layer. Journal of Thermal Biology. 26: 537-545.

Gorewit, R.C., M.C. Aromando, and D.G. Bristol. 1989. Measuring bovine mammary gland blood flow using a transit time ultrasonic flow probe. Journal of Dairy Science 72(7):1918-1928.

Hurley, W. 2010. Lactation biology website, University of Illinois, Chapter 7: Mammary macrostructure, dairy cow anatomy. http://classes.ansci.illinois.edu/ansc438/mamstructure/anatomy_7.html; accessed Nov. 14, 2011 
292 Janeczeck, W., B. Chudoba-Drozdowska, Z. Samborski, \& A. Kusz 1995. Skin temperature

293 changes of the cow mammary gland and the heat flux from its surface before and after milking.

294 Archivum Veterinarium Polonicum 35(1-2):35-44.

295

296

297

Jordan, E.R. 2003. Effect of heat stress on reproduction. J. Dairy Sci. 86 :(E. Suppl.) E104E114.

300 October 23, 2015.

301 Pennes, H.H., 1948. Analysis of tissue and arterial blood temperature in the resting human

302 forearm. J. Appl. Phys. 1, 93-122.

303 Patankar, S.V. 1980. Numerical Heat Transfer and Fluid Flow. New York, N.Y.: 304 Hemisphere/McGraw Hill.

Peeters, G., A. Houvenaghel, E. Roets, A.M. Massart-Leën, R. Verbeke, G. Dhondt and F.

307 Verschooten. 1979. Electromagnetic blood flow recording and balance of nutrients in the udder

308 of lactating cows. J. Anim. Sci. 48(5):1143-1153.

310 Smith, R. E., M. E. Heath, \& D. L. Ingram. 1977."Role of the Udder in Heat Loss from the

311 Sheep." Journal of Thermal Biology 3(3):125-128.

St-Pierre N. R., B. Cobanov, and G. Schnitkey. 2003._Economic losses from heat stress by US 314 livestock industries. J. Dairy Science. 86 :(13 Supplement): E52-E77. 
Table 1 Model inputs

\begin{tabular}{cccc}
\hline Name & Symbol & Value & Unit \\
\hline Tissue thermal conductivity & $\mathrm{k}$ & 0.6 & $\mathrm{~W} / \mathrm{m} \cdot \mathrm{K}$ \\
Tissue density & $\rho$ & 998.2 & $\mathrm{~kg} / \mathrm{m}^{3}$ \\
Tissue specific heat & $\mathrm{c}$ & 3600 & $\mathrm{~J} / \mathrm{kg} \cdot \mathrm{K}$ \\
Blood density & $\rho_{\mathrm{b}}$ & 1060 & $\mathrm{~kg} / \mathrm{m}^{3}$ \\
Blood specific heat & $c_{\mathrm{b}}$ & 4181.3 & $\mathrm{~J} / \mathrm{kg} \cdot \mathrm{K}$ \\
Blood flow rate & $\dot{V}_{b}$ & $3.2 \times 10^{-3}$ & $\mathrm{~m}^{3} / \mathrm{s} \cdot \mathrm{m}^{3}$ tissue \\
Metabolic heat production rate & $\mathrm{Q}_{\mathrm{m}}$ & 1946 & $\mathrm{~W} / \mathrm{m}^{3}$ \\
Air density & $\rho_{\mathrm{a}}$ & 1.2 & $\mathrm{~kg} / \mathrm{m}^{3}$ \\
Dynamics viscosity of air & $\mu$ & $1.79 \times 10^{-5}$ & $\mathrm{~Pa} \cdot \mathrm{s}$ \\
\hline
\end{tabular}

Table 2. Predicted heat flux of the udder versus blood circulation time ${ }^{1}$

\begin{tabular}{|c|c|c|c|}
\hline \multirow{2}{*}{$\begin{array}{l}\text { Heat flux } \\
\left(\mathrm{W} / \mathrm{m}^{2}\right)\end{array}$} & \multicolumn{3}{|c|}{ Blood circulation time (minute) } \\
\hline & 2 & 3 & 4 \\
\hline Sensible & 212 & 252 & 271 \\
\hline Latent & 80 & 86 & 89 \\
\hline Total & 292 & 338 & 360 \\
\hline
\end{tabular}


Table 3. Predicted heat flux of the udder versus blood-flow rate ${ }^{1}$

\begin{tabular}{|c|c|c|c|}
\hline \multirow{2}{*}{$\begin{array}{l}\text { Heat flux } \\
\left(\mathrm{W} / \mathrm{m}^{2}\right)\end{array}$} & \multicolumn{3}{|c|}{ Blood-flow rate $\left(\mathrm{m}^{3} /\left(\mathrm{s} \cdot \mathrm{m}^{3}\right.\right.$ of tissue $\left.)\right)$} \\
\hline & $2.2 \times 10^{-3}$ & $3.2 \times 10^{-3}$ & $4.2 \times 10^{-3}$ \\
\hline Sensible & 229 & 252 & 272 \\
\hline Latent & 82 & 86 & 89 \\
\hline Total & 311 & 338 & 361 \\
\hline
\end{tabular}

339

340 


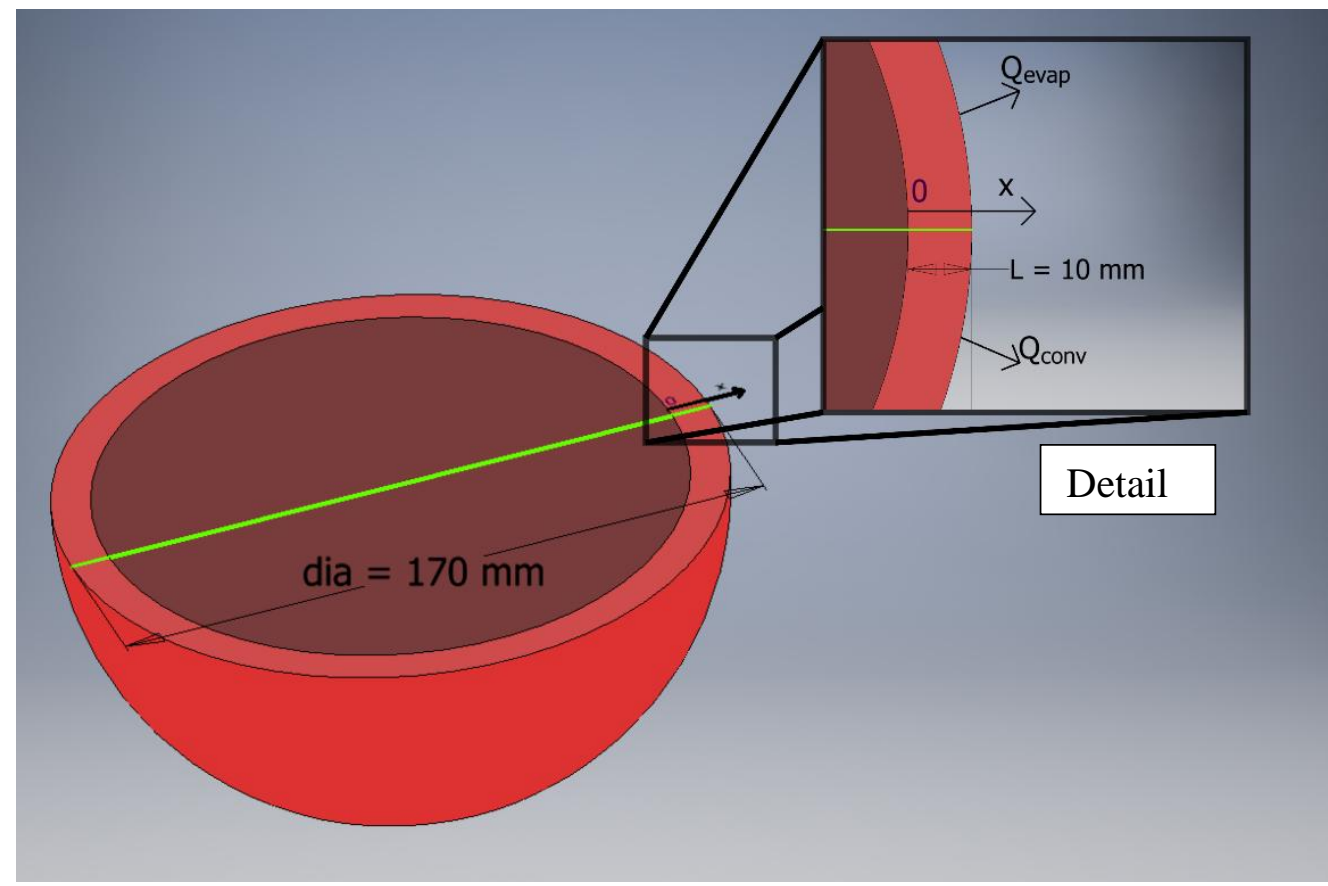

Figure 1. Semi spherical representation of the udder and a detail of 1-D heat flow through a 10-mm outer layer which represents the assumed tissue thickness of the semi sphere.

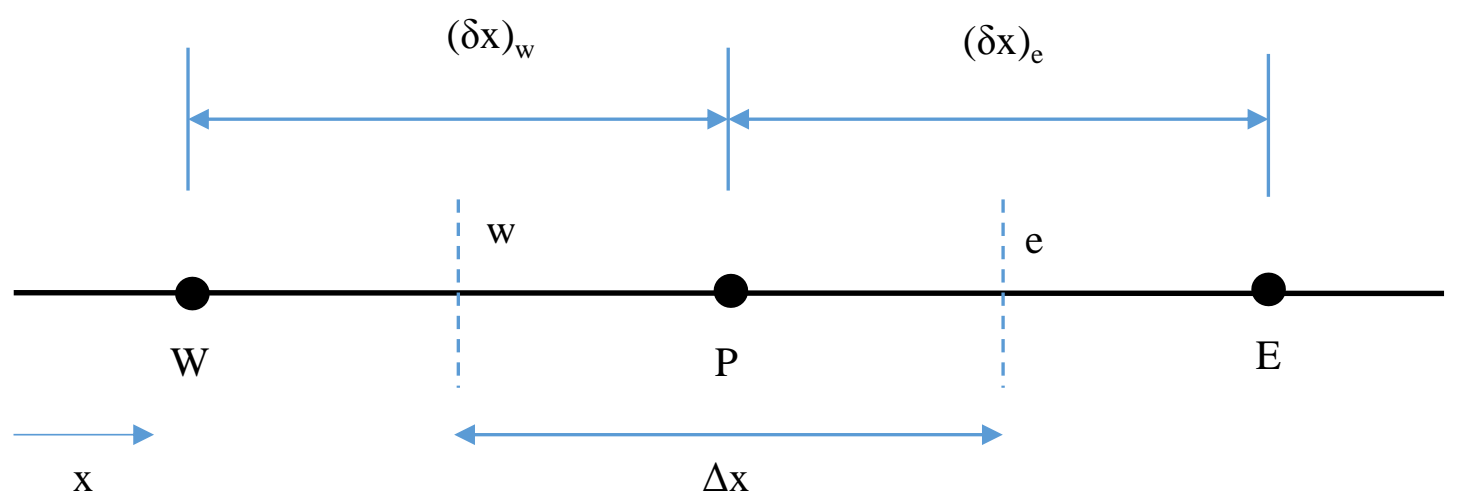

349 Figure 2. Grid-point cluster for one-dimensional problem. $P$ represents center node of the 350 control volume, $E$ and $W$ represent nodes at east and west of Node $P$, respectively, $e$ and $w$ are 351 control surfaces. 


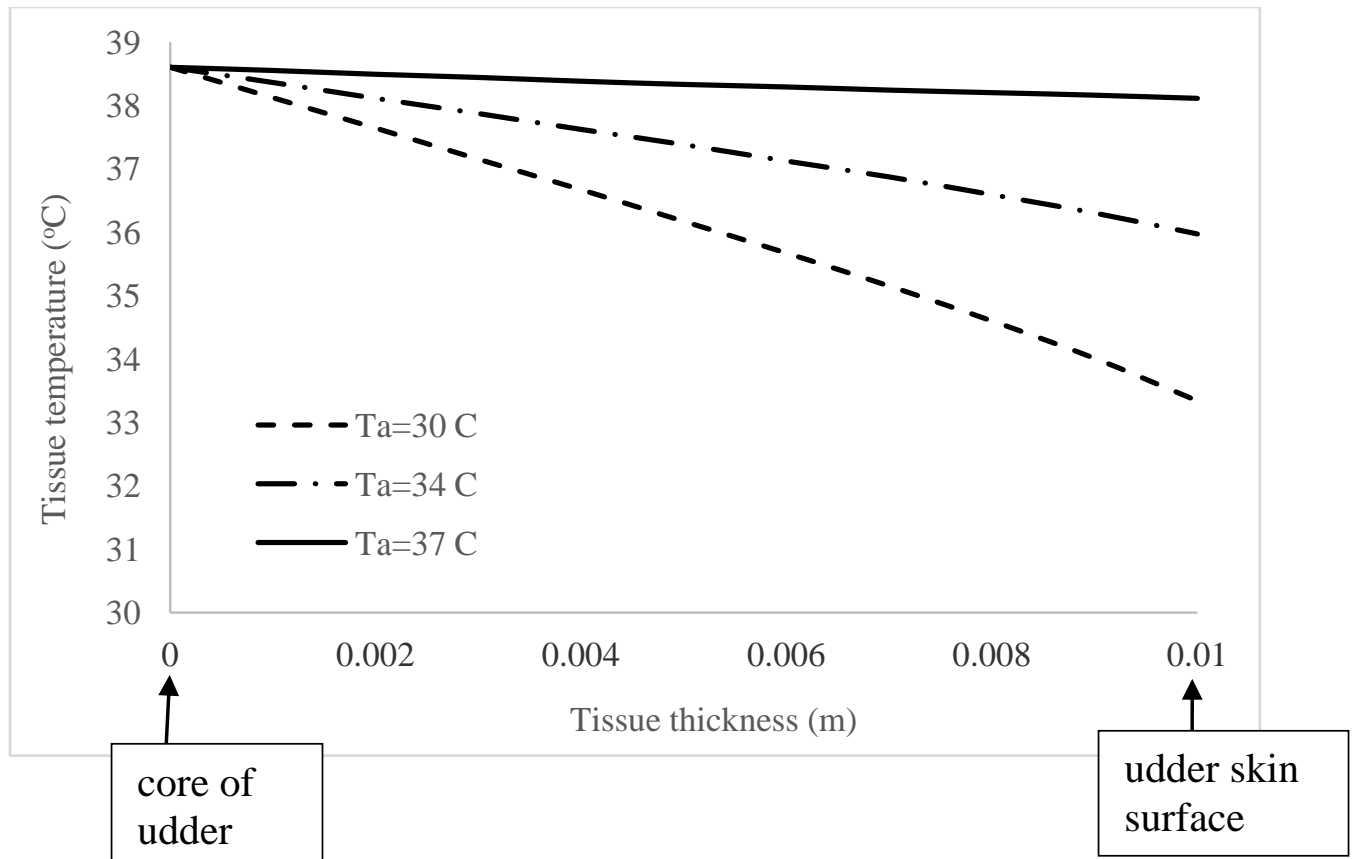

Figure 3. Temperature profile through the tissue for blood-circulation time of $3 \mathrm{~min}$. and bloodflow rate of $3.2 \times 10^{-3}\left(\mathrm{~m}^{3} / \mathrm{s} \cdot \mathrm{m}^{3}\right.$ of tissue).

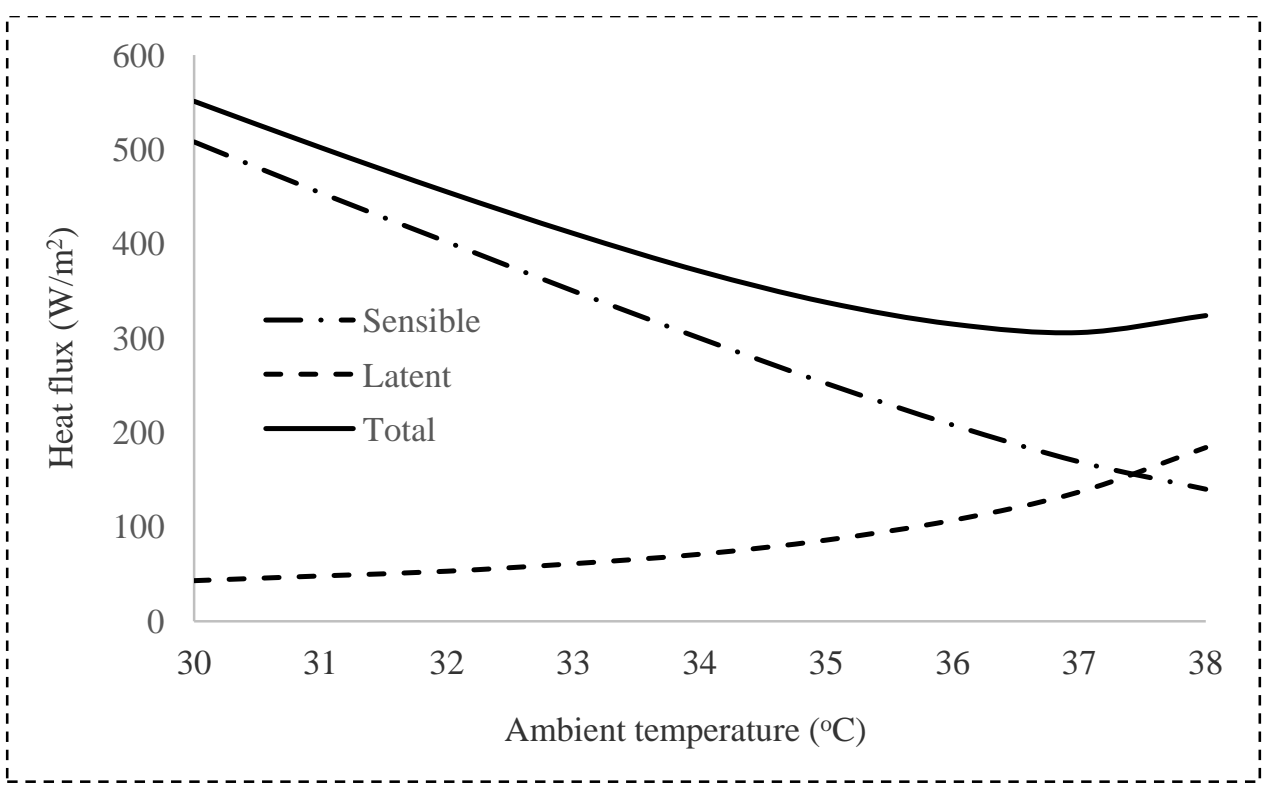

Figure 4. Heat flux (sensible, latent and total) versus ambient air temperature for bloodcirculation time of $3 \mathrm{~min}$. and blood-flow rate of $3.2 \times 10^{-3}\left(\mathrm{~m}^{3} / \mathrm{s} \cdot \mathrm{m}^{3}\right.$ of tissue). 